ACTA AGROBOTANICA

Vol. 58, z. 12005

s. 2328

\title{
Occurrence of Stagonospora nodorum glume blotch of wheat in the region of middle - southern Poland
}

\section{MARIOLA GŁAZEK, BARBARA KRZYZIŃSKA, AGNIESZKA MĄCZYŃSKA}

\author{
Plant Protection Institute in Poznan, Sośnicowice Branch, \\ ul. Gliwicka 29, 44153 Sośnicowice \\ m.glazek@ior.gliwice.pl
}

(Received: 15.03.2005)

\begin{abstract}
Summary
Long-term research work was performed in the years 1996-2002 on the occurrence and significance of winter wheat glume blotch (Stagonospora nodorum) in the region of middle-southern Poland. It was stated that the disease occurred every year at different intensity and this was dependent on the amount of rainfall during the vegetative period, especially in June. Winter wheat was strongly infected in the years 1999 and 2002 when rainfall in June was the highest. The lowest level of infection was recorded in the year 2000 characterized by the lowest rainfall in this month. Full chemical protection with broad spectrum fungicides performed once at GS 49-55 and always significantly increased grain yield, but the increase was the highest in the years of the highest ear infection by $S$. nodorum. It was concluded that in experimental period glume blotch of winter wheat could be considered as a disease of the greatest importance in the region of middle Southern Poland, and thus creation a serious threat to winter wheat cultivated in this area.
\end{abstract}

Key words: Stagonospora nodorum, winter wheat, middle sourthen Poland

\section{INTRODUCTION}

Stagonospora glume and leaf blotch of wheat occurs commonly in Poland and has a significant influence on reducing grain yield. In the years of epidemics it can cause yield losses as high as 50-60\%. Apart of lowering grain yield it negatively affects its quality, mainly because the reduction of 1000 grain weight. Because of a high significance of this disease also in the region of middle-southern Poland the research was undertaken in winter wheat cultures on the occurrence and intensity of the disease and the effect on yield. The aim of this investigation was to determine severity of the disease and the development of epidemics as related to some factors, especially to the amount of rainfall in the vegetative period. The influence of leaf and glume blotch caused by S. nodorum on the amount of grain yield was also estimated in winter wheat fields protected and unprotected with fungicides. 


\section{MATERIAL AND METHODS}

Field observations were performed in the years 1996-2002 in the region of Institute of Plant Protection Branch in Sośnicowice and the neighbouring fields. Environmental and agrotechnical conditions of this area are representative for middle-Southern Poland and thus the collected data can be regarded as characteristic for the whole region. Analysis of plant infection was performed in each vegetative period on 5-6 fields of winter wheat, mainly on cultivars Kobra and Mikon, and occasionally on Busard and Korweta. Data for every year were averaged and then analysed using statistical methods. Also other fungal diseases: leaf blotch caused by Septoria tritici, powdery mildew (Blumeria graminis), tan spot (Pyrenophora tritici-repentis), brown rust (Puccinia recondita f.sp.tritici) and head blight (Fusarium avenaceum, Fusarium culmorum) were recorded from the early growth stages GS 35-37 to the stage of grain ripening GS 83. Per cent of infected leaf area on flag (L-1) and L-2 leaves, glume area infection and green assimilating leaf area was determined on one hundred plants taken at random from each field. Weather conditions, and especially the amount of rainfall were recorded and their influence on the development and severity of infection was estimated. A detailed analysis of the effect of chemical protection with fungicides on grain yield was performed, paying a special attention to the years when a high infection of wheat by $S$. nodorum occurred. Chemical protection of the investigated fields was performed once, at growth stage GS 49-55. In each case broad spectrum fungicides were used to ensure optimal control of occurring diseases.

\section{RESULTS}

In the region of Sośnicowice and neighbouring fields in the years 1996-2002 differentiated levels of leaf and ear infection of winter wheat was observed. S. nodorum the cause of glume and leaf blotch was observed every year (Table 1). The intensity of infection was analysed in relation to decade and monthly sums of rainfall. In the years 1999 and 2002 the highest level of glume infection by S. nodorum (58\% infected area) was recorded, and in the year 2001 glume infection amounted to $33,88 \%$. Monthly sums of rainfall in the years 1999 and 2002 in June were high or very high and amounted to $152 \mathrm{~mm}$ and $300 \mathrm{~mm}$, respectively. In the year 2001 monthly sum of rainfall was also high and amounted to $96 \mathrm{~mm}$, while June of 2000 was characterized by the lowest amount of rainfall $(19.9 \mathrm{~mm})$ and a very low ear infection by $S$. nodorum (2.72\% infected area). Despite of a considerable amount of rainfall in June of 1998 (81 $\mathrm{mm}$ ) ear infection by $S$. nodorum was low (1.23\%) infected ear area, which did not statistically differ from the data obtained in 2000 . The amount of rainfall in July did not have a distinct influence on the intensity of glume blotch.

In Table 2 data are presented on the intensity of winter wheat infection by pathogenic fungi on chemically protected with fungicides and unprotected fields in the years 1999 and 2002 (the highest infection with glume blotch at GS 83) and in the year 2000 (significantly lowest glume blotch at GS 83). Chemical protection significantly reduced leaf infection by S. nodorum at GS 75 in the years 1999 and 2002, but not in the year 2000 when leaf 


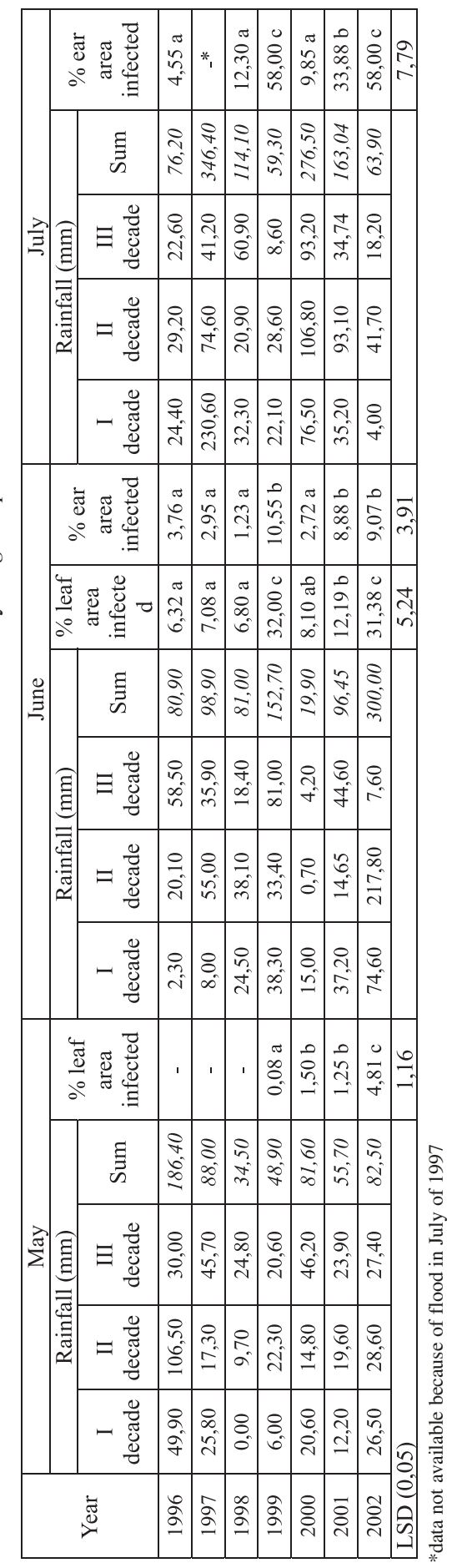

\begin{tabular}{|c|c|c|c|c|c|c|c|c|}
\hline \multicolumn{2}{|c|}{ 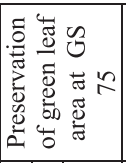 } & $\begin{array}{l}0 \\
\stackrel{2}{8} \\
8\end{array}$ & $\begin{array}{l}0 \\
2 \\
\infty \\
\infty \\
\infty\end{array}$ & $\begin{array}{l}0 \\
8 \\
i \\
i\end{array}$ & $\begin{array}{l}\check{0} \\
\infty \\
\infty \\
\hat{a}\end{array}$ & $\begin{array}{l}0 \\
\vdots \\
\approx \\
\forall\end{array}$ & $\begin{array}{l}0 \\
8 \\
\infty \\
\infty\end{array}$ & $\left|\begin{array}{c}\infty \\
\infty \\
\infty \\
\infty\end{array}\right|$ \\
\hline \multirow{4}{*}{ 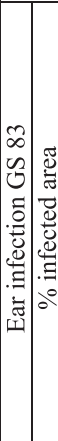 } & 气્ & $\begin{array}{l}\overrightarrow{0} \\
\hat{0} \\
\hat{\sigma}\end{array}$ & $\begin{array}{l}0 \\
\stackrel{2}{ } \\
\infty \\
\infty\end{array}$ & $\begin{array}{c}0 \\
\infty \\
\infty \\
\infty \\
\infty\end{array}$ & 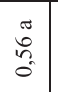 & $\begin{array}{l}\vec{b} \\
\infty \\
\infty \\
0 \\
0\end{array}$ & $\begin{array}{l}\tilde{n} \\
\tilde{n} \\
\tilde{m}\end{array}$ & \\
\hline & 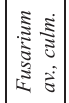 & $\begin{array}{l}0 \\
\hat{0} \\
+\end{array}$ & $\begin{array}{l}0 \\
: \\
:\end{array}$ & $\begin{array}{l}0 \\
\vec{\infty} \\
0 \\
0\end{array}$ & 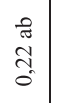 & $\begin{array}{l}\overrightarrow{0} \\
\infty \\
\infty \\
i\end{array}$ & $\underset{\tilde{J}}{\stackrel{0}{0}}$ & $\begin{array}{l}0 \\
0 \\
0 \\
0\end{array}$ \\
\hline & 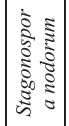 & $\begin{array}{l}\overrightarrow{8} \\
8 \\
\infty \\
i n\end{array}$ & $\begin{array}{l}0 \\
8 \\
=\end{array}$ & $\begin{array}{l}\stackrel{0}{\cong} \\
\stackrel{\sim}{\sim}\end{array}$ & $\frac{\pi}{m_{n}}$ & $\begin{array}{l}\overrightarrow{0} \\
8 \\
\infty \\
\infty\end{array}$ & $\left|\begin{array}{c}0 \\
\pi \\
\tilde{\infty} \\
0 \\
n \\
-1\end{array}\right|$ & $\vec{f}$ \\
\hline & 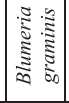 & $\begin{array}{l}\pi \\
8 \\
0\end{array}$ & $\begin{array}{l}\pi \\
8 \\
8 \\
0\end{array}$ & \begin{tabular}{l}
0 \\
\multirow{n}{\alpha}{} \\
0
\end{tabular} & $\begin{array}{l}\pi \\
\tilde{0} \\
0\end{array}$ & $\begin{array}{l}\pi \\
8 \\
8 \\
0\end{array}$ & $\begin{array}{l}\pi \\
8 \\
0 \\
0\end{array}$ & $0_{0}^{*}$ \\
\hline \multirow{4}{*}{ 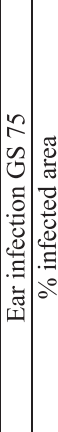 } & 章 & $\begin{array}{l}0 \\
\stackrel{2}{\circ} \\
\infty\end{array}$ & $\begin{array}{c}\sigma \\
\dot{0} \\
\infty \\
i\end{array}$ & $\begin{array}{c}0 \\
\infty \\
\infty \\
i\end{array} \mid$ & 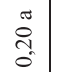 & $\begin{array}{l}0 \\
\stackrel{n}{a} \\
\cong\end{array}$ & $\begin{array}{l}\pi \\
\tilde{0} \\
0 \\
0\end{array}$ & $\left|\begin{array}{c}\text { ते } \\
\text { mat }\end{array}\right|$ \\
\hline & 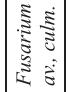 & $\begin{array}{l}\vec{j} \\
\dot{m}\end{array}$ & $\begin{array}{l}\overrightarrow{0} \\
\stackrel{\sim}{-}\end{array}$ & $\begin{array}{l}8 \\
\stackrel{8}{2} \\
=\end{array}$ & ڤ్ & $\begin{array}{l}\vec{J} \\
\mathbb{0} \\
i\end{array}$ & \begin{tabular}{l}
$\pi$ \\
\multirow{2}{*}{} \\
0
\end{tabular} & ลี. \\
\hline & 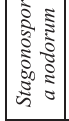 & $\begin{array}{l}0 \\
\text { Oे } \\
+\end{array}$ & $\stackrel{\pi}{\stackrel{N}{\sim}}$ & 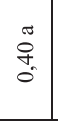 & $\begin{array}{l}\pi \\
8 \\
8\end{array}$ & $\begin{array}{c}0 \\
\vdots \\
\vdots \\
a\end{array}$ & $\begin{array}{c}\pi \\
\tilde{y} \\
0 \\
0\end{array}$ & {$\left[\begin{array}{l}\infty \\
\infty \\
-1\end{array}\right]$} \\
\hline & 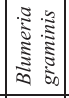 & $\stackrel{\sigma}{ \pm}$ & 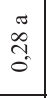 & $\begin{array}{c}0 \\
\infty \\
0 \\
0 \\
0\end{array}$ & $\stackrel{\pi}{8}$ & $\begin{array}{l}\pi \\
\tilde{c} \\
0 \\
-1\end{array}$ & $\begin{array}{l}\pi \\
\tilde{8} \\
0 \\
0\end{array}$ & 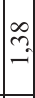 \\
\hline \multirow{5}{*}{ 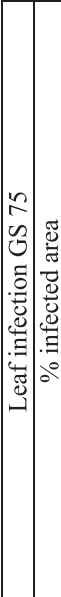 } & 咅 & $\begin{array}{l}\stackrel{0}{\circ} \\
\text { aे }\end{array}$ & $\begin{array}{l}\stackrel{0}{\varrho} \\
= \\
=\end{array}$ & $\mid \begin{array}{l}0 \\
\dot{q} \\
\dot{q}\end{array}$ & $\underset{i}{\stackrel{\pi}{I}}$ & \begin{tabular}{l}
0 \\
\multirow{J}{*}{} \\
$\tilde{f}$ \\
$\tilde{f}$
\end{tabular} & $\begin{array}{l}\sigma \\
0 \\
0 \\
+ \\
+\end{array}$ & $=$ \\
\hline & 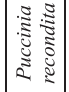 & ס̊. & $\begin{array}{l}\pi \\
8 \\
0\end{array}$ & $\left|\begin{array}{l}0 \\
\dot{0} \\
\dot{0} \\
i \\
i\end{array}\right|$ & $\begin{array}{l}\pi \\
8 \\
0\end{array}$ & $\begin{array}{l}0 \\
\infty \\
\infty \\
0 \\
0\end{array}$ & $\begin{array}{c}\sigma \\
0 \\
0 \\
0 \\
0\end{array}$ & 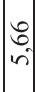 \\
\hline & 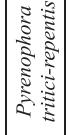 & $\begin{array}{l}\pi \\
8 \\
8\end{array}$ & $\begin{array}{l}\pi \\
8 \\
8 \\
0\end{array}$ & $\begin{array}{c}0 \\
\hat{2} \\
\tilde{n}\end{array}$ & \begin{tabular}{l}
$\pi$ \\
\multirow{0}{0}{} \\
$\stackrel{0}{0}$ \\
0
\end{tabular} & $\begin{array}{c}0 \\
+ \\
\dot{n} \\
n\end{array}$ & $\left|\begin{array}{l}0 \\
0 \\
0 \\
0\end{array}\right|$ & $\begin{array}{l}0 \\
\text { î. }\end{array}$ \\
\hline & 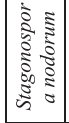 & $\begin{array}{l}0 \\
\stackrel{n}{0} \\
\infty\end{array}$ & $\begin{array}{l}\overrightarrow{0} \\
\underset{\sim}{\Delta} \\
\infty\end{array}$ & 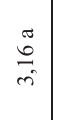 & 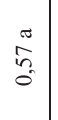 & $\begin{array}{l}0 \\
\infty \\
m \\
\vec{m}\end{array}$ & $\begin{array}{l}n \\
2 \\
\tilde{m} \\
n\end{array} \mid$ & $\begin{array}{l}\infty \\
m \\
\stackrel{\tau}{2}\end{array}$ \\
\hline & 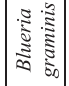 & $\begin{array}{l}\vec{n} \\
\tilde{n}\end{array}$ & $\begin{array}{l}0 \\
\dot{0} \\
\infty \\
i\end{array}$ & $\begin{array}{l}8 \\
8 \\
0 \\
i\end{array}$ & $\begin{array}{l}0 \\
\text { बह } \\
\text { बे } \\
0\end{array}$ & $\begin{array}{l}\pi \\
\tilde{n} \\
0 \\
0\end{array}$ & $\begin{array}{l}\pi \\
8 \\
0 \\
0\end{array}$ & $\begin{array}{l}\text { N} \\
\text { ה }\end{array}$ \\
\hline \multirow{2}{*}{\multicolumn{2}{|c|}{ 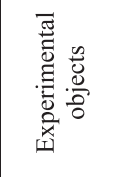 }} & \multicolumn{2}{|c|}{ 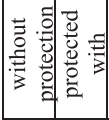 } & $=$ & 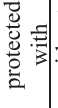 & & & \\
\hline & & \multicolumn{2}{|c|}{$\Xi$} & \multicolumn{2}{|c|}{ 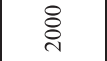 } & \multicolumn{2}{|c|}{ ర్రి } & \\
\hline
\end{tabular}


infection by this pathogen was the lowest. At GS 83 a positive, significant effect of fungicide application on the reduction of glume blotch was recorded in each year (1999, 2000 and 2002). Chemical control of diseases always had a positive, significant effect on preservation of green leaf area recorded at GS 75, as well as on the sum of leaf infection by all pathogens recorded at this growth stage. It should also be noted that the positive, significant effect of chemical disease control on leaf healthiness in 2000 (the year of low glume blotch) was evidently due to a very good control of brown rust, the disease occurring at a relatively high intensity ( $26 \%$ infested leaf area). Table 3 presents the data on the influence of chemical control on the amount of grain yield. It can be clearly seen that the highest yield increase was obtained on treated fields in the years of the highest ear infection by $S$. nodorum, that amounted to $1.22 \mathrm{t} / \mathrm{ha}$ and $1.32 \mathrm{t} / \mathrm{ha}$ ( $18 \%$ and $21 \%$ increase) in the years 1999 and 2002, respectively. In the year 2000 grain yield increase obtained as a result of chemical disease control was also significant. It amounted to $0.84 \mathrm{t} / \mathrm{ha}$ ( $14 \%$ increase), and was much lower than in the years 1999 and 2002.

Table 3.

Effect of chemical control of winter wheat diseases on grain yield and preservation of green leaf area

\begin{tabular}{|c|c|c|c|c|c|}
\hline \multirow{2}{*}{\multicolumn{2}{|c|}{ Experimental objects }} & \multirow{3}{*}{$\begin{array}{c}\text { Green leaf area } \\
\text { GS } 75 \\
60,30 b\end{array}$} & \multirow{3}{*}{$\begin{array}{c}\begin{array}{c}\text { Grain yield } \\
\text { t/ha }\end{array} \\
6,43 \mathrm{ab}\end{array}$} & \multicolumn{2}{|c|}{$\begin{array}{l}\text { Increase as related } \\
\text { to non-protected objects }\end{array}$} \\
\hline & & & & $\mathrm{t} / \mathrm{ha}$ & $\%$ \\
\hline \multirow{2}{*}{1999} & $\begin{array}{l}\text { without } \\
\text { protection }\end{array}$ & & & 0,00 & 100,00 \\
\hline & $\begin{array}{l}\text { protected with } \\
\text { fungicides }\end{array}$ & $88,90 \mathrm{c}$ & $7,65 \mathrm{c}$ & 1,22 & 118,97 \\
\hline \multirow{2}{*}{2000} & $\begin{array}{l}\text { without } \\
\text { protection }\end{array}$ & $59,60 \mathrm{~b}$ & $5,68 \mathrm{a}$ & 0,00 & 100,00 \\
\hline & $\begin{array}{c}\text { protected } \\
\text { with fungicides }\end{array}$ & $97,88 d$ & $6,52 \mathrm{~b}$ & 0,84 & 114,79 \\
\hline \multirow{2}{*}{2002} & $\begin{array}{c}\text { without } \\
\text { protection }\end{array}$ & $41,25 a$ & $6,22 \mathrm{ab}$ & 0,00 & 100,00 \\
\hline & $\begin{array}{l}\text { protected with } \\
\text { fungicides }\end{array}$ & $85,00 c$ & $7,54 \mathrm{c}$ & 1,32 & 121,22 \\
\hline \multicolumn{2}{|r|}{$\operatorname{LSD}(0,05)$} & 8,86 & \multicolumn{3}{|l|}{0,84} \\
\hline
\end{tabular}

\section{DISCUSSION}

The fungus Stagonospora nodorum commonly occurs in Europe, especially in northern geographic latitudes (Eyal, 1999). Reports on the occurrence of septoria diseases (Septoria tritici, Stagonospora nodorum) have been coming from various continents with the exception of some parts of Asiatic continent South western regions (E y a l, 1999 and 1997). Glume blotch of wheat caused by S. nodorum is considered as one of the most important diseases (Murray et al., 1998) having a high impact on the decrease of grain yield even by $50-60 \%$. Kernels are shrivelled and have a lower unit weight (E y al et al., 1987; K orb as, 2001). The fungus causes extensive leaf and glume necroses and contributes to the reduction of assimilation by upper plant organs (Pokacka, 1985; Zillinsky, 1983), thereby weakening grain filling 
(E y a 1, 1999). Our observations, confirmed by the isolation of the pathogen show that in less favouring conditions for disease development symptoms in the form of short, black streaks can also occur. Primary infection source consists of ascospores of Phaeosphaeria nodorum which are dispersed with air currents (Mittelstäd et al., 1987 and Góral, Arseniuk et al., 1994), the former authors working in Saxony cought huge quantities of airborn ascospores of Phaeosphaeria nodorum by means of suction sporetrap, mainly in the autumn and also in the spring over the fields where wheat stubbles were present. They indicated that importance of ascospores as inoculum source has been previously underestimated. Other sources of infection are: infected kernels and plant debris (Korbas, 2001; Ey al, 1997; Ey al et al., 1999) colonized by the pathogen. In this case conidia are assumed to be a main source of primary inoculum. However the most important for the development of epidemics is dispersal of conidia by splashing or windblown rain (Eyal, 1997 and 1999). In the course of performed research it was stated that the highest leaf and glume infection took place when sum of rainfall in only one decade of June was the highest and amounted to 81 $\mathrm{mm}$ (1999) and $217 \mathrm{~mm}$ (2002). This is in agreement with the data presented by E y al (1987) and Nieróbca (2002). The uniform distribution of rainfall in June of 1999 and 2002 assured the maintenance of relative air humidity on the average level around $75 \%$ or more, with no prolonged dry periods, which was favourable for a faster and more intensive disease development. According the research performed by J org en sen et al. (1999) there was stated a relation between the number of days with $1 \mathrm{~mm}$ rainfall or more the disease development on upper winter wheat leaves. This can be related to observations performed in middle-Southern Poland a lower level of infection was stated when sum of rainfall in June was low. A higher amount of rainfall in July was of less importance for the development of infection because glume tissue of winter wheat plants approaching maturity is less susceptible to the development of pathogen and the period of time for its colonization before harvest is limited.

The application of fungicides at stage GS 49-55, which is in agreement with principles presented by Cook (1999), confined the infection and development of the pathogen, and thus contributed to the increase of grain yield by $18 \%$ in 1999 and $21 \%$ in 2002. In the year of a low incidence of S. nodorum and high infection of leaves with other pathogens, mainly Puccinia recondita f.sp.tritici an experimental fields the increase of grain yield was lower and amounted to $14 \%$. This indicates that the harmfulness of glume blotch of winter wheat is higher in the region of middle-Southern Poland than infection of leaves, even in the case of a high disease intensity.

1. In the years 1996-2002 a regular occurrence of winter wheat glume and leaf blotch (Stagonospora nodorum) was stated in the region of middle-Southern Poland.

2. Dependence of the occurrence and intensity of winter wheat glume blotch and sums of rainfall in June was stated.

3. In conditions of performed research winter wheat glume blotch caused by S. nodorum had a greater negative influence on the amount of grain yield than other occurring diseases.

4. Obtained results have a practical significance indicating threat of S. nodorum infection of winter wheat cultivated in the middle-Southern Poland in conditions of sufficient amount of rainfall, especially in June. 


\section{REFERENCES}

Cook R. J. 1999. Management by Chemicals; 286 298. [In:] Lucas J.A., Bowyer P., Anderson H. M. Septoria on Cereals: a Study of Pathosystems.

Ey a 1 Z. 1999. The Septoria tritici and Stagonospora nodorum blotch diseases of wheat. Euro pean Journal of Plant Pathology 105: 629641.

Eyal Z., Scharen A. L., Prescott J. M., M. van Ginkel. 1987. The Septoria Diseases of Wheat: Concepts and methods of disease management.

Góral T., Arseniuk E. and Scharen A. L. 1994. Spore dispersal studies of Phaeospha eria nodorum. Hodowla Roślin Aklimatyzacja i Nasiennictwo.38: 235239.

Korbas M. 2001. Choroby i szkodniki zbóż; Multum, Poznań: 74.

Jorgensen L. N., Secher B. J. M., Hos s y H. 1999. Decision Support Systems Featuring Septoria Management. [In:] Lucas J. A., Bowyer P., Anderson H. M. 1999. Septoria on Cereals: a Study of Pathosystems. CABI Publishing New York, pp. 251272.

Mittelstäd A., Fehrmann H. 1987. Zum Auftreten der Hauptfruchtform von Septoria nodorum in der Bundesrepublik Deutschland. Zeitschrift für Pflanzenkrankheiten und Pflanzenschutz.94 (4): 380385.

Murray T. D., Parry D.W., Cattlin N. D. 1998. Diseases of Small Grain Cereal Crops, Manson Publishing, Barcelona, pp. 7374.

Nieróbca A. 2002. Prognozowanie chorób na podstawie bieżących danych meteorologicz nych. Pamiętnik Puławski Materiały Konferencji, Zeszyt 130: 495502.

Pokacka Z. 1985. Badania nad plamistościami liści pszenicy ze szczególnym uwzględnie niem roli Septoria nodorum Berk. Prace Naukowe Instytutu Ochrony Roślin. T. XXVII, Z. 2; 533 .

Zillinsky F. J. 1983. Common Diseases of Small Grain Cereals, CIMMYT, Mexico, pp. 4142.

\section{Występowanie septoriozy plew pszenicy powodowanej przez Stagonospora nodorum na pszenicy ozimej w rejonie Polski południowo-środkowej}

\section{Streszczenie}

Przeprowadzono wieloletnie badania nad występowaniem i znaczeniem septoriozy plew pszenicy powodowanej przez Stagonospora nodorum na pszenicy ozimej w latach 1996-2002 w rejonie Polski południowo-środkowej. Stwierdzono, że choroba występowała w każdym roku jednakże w różnym nasileniu, które zależało od sumy opadów deszczu w czasie sezonu wegetacyjnego a szczególnie w czerwcu. Pszenica ozima była szczególnie silnie porażona w latach 1999 i 2002 kiedy suma opadów deszczu była w czerwcu najwyższa. Najniższy poziom porażenia pszenicy stwierdzono w 2000 roku, który charakteryzował się najmniejszą sumą opadów deszczu w czerwcu. Pełna chemiczna ochrona przy zastosowaniu fungicydów o szerokim spektrum działania przeprowadzona raz w fazie rozwojowej roślin GS 49-55 zawsze znacząco wpływała na wzrost plonu ziarna. Wzrost plonu był najwyższy w latach najwyższego porażenia kłosów przez grzyb Stagonospora nodorum. Uzyskane wyniki wskazują, że w czasie objętym badaniami septorioza plew pszenicy była chorobą o największym znaczeniu w rejonie Polski południowo-środkowej i stanowiła ważne zagrożenie dla pszenicy ozimej uprawianej w tym rejonie. 